\title{
Gilbert Stringer \& New Zealand public broadcasting in the 1960s
}

\section{PATRICK DAY}

Gilbert Stringer was the inaugural director-general of the New Zealand Broadcasting Corporation (NZBC) from its institution in 1962 to his retirement in July 1970. He was a career public servant who, by 1962 , had already spent many years in New Zealand broadcasting. My intention is to examine his contribution to $\mathrm{New}$ Zealand public broadcasting, which I am dating, if at all, from the inauguration of the NZBC in 1962. Thus I am arguing that previous broadcasting in New Zealand was not public. In practice this means distinguishing government and public broadcasting and my focus is largely on the extent to which the NZBC can be regarded as a public as opposed to a government broadcaster.

The pre-NZBC broadcaster was the New Zealand Broadcasting Service (NZBS). It was a government department and it broadcast as an arm of government. Its priorities were the concerns of the government of the day rather than those of the public broadcaster. I began by accepting the statement 'public broadcasting begins with the $\mathrm{NZBC}^{\prime}$ as more rhetorical than contentious but then became less sure of the public broadcasting status of NZBC broadcasting. The lack of clarity lies with both that murky concept and its practice in New Zealand. Here I follow Stringer as a pivotal figure in the New Zealand definition and experience of public broadcasting.

New Zealand is an intriguing place to examine the nature of public broadcasting for generally it has the hallmark of being non-commercial. In New Zealand, for reasons that have to do with the politics of the mid 1930s, the NZBS had both commercial and non-commercial radio stations. This arrangement continued with the NZBC and was applied to television stations. Like the $x$ class radio stations, eight stations in secondary centres that opened from 1949, for part of the transmission time they were commercial and for part of the time they were not. Not only is New Zealand's so-called public broadcasting commercial broadcasting, it is also a commercial broadcasting that has intensified over the years. Within the NZBS the non-commercial stations had very much the lesser share

Above: Gilbert Stringer pictured in April 1962, as the NZBC begins. Photograph: Evening Post.

of the audience but, in spite of this, only well into the 1950 s did the commercial network rise in the departmental priorities towards equality. There are indications of this anti-commercial attitude within the NZBC but much more strong is the willingness to be a commercial broadcaster. Over the years television stations, as with the $x$ class radio stations, increased their commercial time. While run as a publicly owned corporation, the NZBC and its successor organisations readily accepted commercial broadcasting, even to the point of introducing spot advertising, a practice from the resolute end of the spectrum of avarice. To compensate for such a characteristic one could require the $\mathrm{NZBC}$ to rate highly on other defining criteria of the concept of public broadcaster.

Here I examine Stringer's contribution to public broadcasting in the areas of first, news and current affairs, and second, institutional autonomy. I do not suggest that these are the only areas of interest. Programme selection, at least, is a third equally important topic for public broadcasting and one which, with Stringer, offers for examination the paternalistic grasp of the public broadcaster. But these first two areas are pivotal in public broadcasting. They also indicate the contrary nature of Stringer. The inability to gain autonomy is the main obstacle to accepting that NZBC broadcasting was truly public broadcasting. Conversely Stringer's initiative in starting news and current affairs indicates an administrative competence and even daring that gave New Zealand broadcasting an activity it had never practised, and is its main claim to the status of a public broadcaster. 


\section{NEWS AND CURRENT AFFAIRS}

Gilbert Stringer's greatest contribution to broadcasting and to New Zealand generally resides in his leadership and seizure of the moment to launch a news organisation within broadcasting. Lionel Sceats, a later director-general, noted of New Zealand broadcasting, 'The changes ... were more extensive after the advent of the news service than ever before. And only naturally so.' The reason the extensive changes were 'only naturally so' has to do with the centrality of news and current affairs to public broadcasting and their absence from previous New Zealand broadcasting. There had been news broadcasts of a sort on radio since the medium began. At first stations gathered news with scissors, by cutting it from newspapers to read after $7 \mathrm{pm}$, after newspaper subscribers had read it first. When the first Labour government turned broadcasting into an arm of government the last thing it wanted was to broadcast the news prepared by its enemies, the newspaper proprietors. Thus it began the Government News Service. From 1937 broadcasts were prepared in the prime minister's office and then in the 1950s within the Department of Tourism and Publicity. The NZBS read the news 'without addition or alteration'. The NZBS was without a journalism section, something essential within the broadcasting organisations of countries with which New Zealand was regarded as comparable.

The Government News Service had two main inadequacies. First, it was politically controlled and regularly politically motivated. Second, it did not have adequate access to non-governmental news, both national and international. Attempts to address the second problem were made on various occasions in the 1950s by applying to join the New Zealand Press Association (NZPA). These were always rejected by a newspaper proprietors' association which saw no reason to increase the journalistic prowess of a competitor.

Apart from the impossibility of obtaining political permission for a news service within broadcasting, its introduction was always hampered by the need to have sufficient staff spread around the country. For Stringer this difficulty was overcome with the arrival of the $x$ class radio stations. Stringer was the principal head office administrator in their planning and establishment. He considered, 'We had the makings of a very good pa [press association] of our own.' There were gaps. Centres such as Taupo, Blenheim, Tokoroa and Taumaranui were not covered by the broadcasting service. In spite of these omissions, Stringer felt able to challenge the press association. Furthermore, now to be a corporation, the broadcasting service could itself decide on the future nature of its news service. Stringer noted: 'It did not need the approval of the government of the day. Whatever pressures the press magnates had on the National government of the time, as it would appear they had in the past, did not apply.' Stringer later stated that he decided, during the period the 1961 Broadcasting Act was being drafted, there would be no further applications by the broadcasting service to the NZPA for membership.

At the time, Stringer was an employee of the NZBS and not even a director-general designate. In theory he was in no position to decide. In practice he was a pivotal administrator and did much to shape the future of broadcasting news and current affairs. When it was clear the NZBC would be instituted, Stringer instructed J H Hall, from the NZBS head office, to prepare a submission for the formation of a news service within broadcasting. This was ready when the corporation was appointed. Board members were presented with the ending of the Government News Service, the history of the rejections from NZPA, plans to begin an NZBC news service, and an assurance from Stringer that the job could be done. It was a fait accompli. The Board approved the proposal at its second meeting, on 2 April 1962, when it also appointed Stringer director-general.

The resolution 'to proceed with the establishment of a news service in sound broadcasting and television' was momentous, not just for the NZBC, but for the NZPA and also for New Zealand. It is one of the country's major changes in the twentieth century. The previous broadcasting news service had been an arm of government to which the traditional journalistic canons did not apply, and the NZPA was itself a stultified organisation. Started in 1880 as a cooperative of newspaper proprietors, the NZPA functioned well as a news source but also ensured the then existing newspapers faced competition only among themselves. In the twentieth century with the rise of the Labour and National parties the New Zealand press, with few exceptions, became a National party supporter. New Zealand became a country with newspapers of similar voice. This political partiality is symptomatic of a wider and shared cultural conservatism. The decision by the NZBC to start its own service led to great changes in the country's understanding of journalism and to the practice of the craft within both the NZBC and the member newspapers of the NZPA.

I do not imply that these changes appeared immediately or even quickly. To a large extent Stringer's confidence that the job could be done within the NZBC was misplaced. The first years of news preparation and presentation within the NZBC were years of considerable difficulty and even incompetence. The resources were not available. The corporation also lacked staff with sufficient experience and expertise to run a news service. Waldo Maguire, head of BBC television news, seconded to the NZBC in 1964 as the inaugural controller of news and current affairs, spoke of the nightly television news broadcast as 'the daily miracle'. Maguire's wonderment was not at the quality or lack of it, but that the news broadcasts went to air at all. 
Stringer's judgement of the capabilities of the corporation and his expectations of his staff were over-optimistic. However this is not to criticise Stringer but to praise him. Without his assertive confidence that the job could be done, the moment would have been lost. A fuller appraisal of the capabilities within the NZBC may have led to a reconsideration of the decision to start a broadcasting news service. More voices, not all careful of democracy and free expression, would have been heard, and who could then tell what proposal may have emerged. Stringer occupied a pivotal position at a critical moment and made the right decision. By doing so he made a contribution of enduring importance to his country. Nor was he let down by contemporary public opinion. Fortunately for the NZBC, its naive and at best barely competent early journalism was accepted by a New Zealand audience that more than matched its broadcasters' lack of sophistication and lack of appreciation of what broadcasting journalism should be.

\section{NZBC AUTONOMY}

Stringer's view was that an independent broadcasting corporation was not possible in New Zealand. To him it was an attempt to set up a state within a state that was itself too small to admit an independent other. Thus Stringer was in the ironic position of being the man required to assert that independence while he, more than anyone, was aware of his likely, even certain, failure. While drafting the 1961 Act he twice approached Arthur Kinsella, the minister of broadcasting, in an attempt to change the national government's plan. Twice he was told the instructions were from cabinet and he, Stringer, should go away and implement them.

Stringer considered there were two main problems. The first faced was the matter of the corporation's financial independence. Stringer's view was that in New Zealand, a small country with periodical trade depressions and cycles, the large-scale capital outlay of a national broadcaster would have to be taken into account by an organisation with a wider concern than the NZBC, presumably either the government or parliament. Certainly the government shared this appraisal. The financial independence of the NZBC was lost before the corporation began, while the legislation was in the drafting stages. A treasury proposal that spending without cabinet approval be limited to $£ 25,000$ was accepted. Similarly any right to borrow funds was subject to the agreement of the minister of finance. Further, the proportion of NZBC income that came from the broadcasting licence fee was controlled by the government. It set the level of the fee. Thus the corporation was always financially in thrall to a government that had considerable control over income and expenditure.

The second difficulty faced and the second defeat for NZBC autonomy was the matter of parliamentary influ- ence on programmes. Stringer regarded freedom from programme interference by parliamentarians as unlikely in New Zealand with its political system that had few seats in the House and a small population per electorate. He considered it unrealistic to expect MPs to not interfere in NZBC day to day activities, to give it real independence. Subsequent events supported Stringer's understanding. The first time a question on the NZBC was asked of Kinsella in the House he suggested he should not answer as it was a matter internal to the corporation. This was not accepted by the Speaker. Thereafter questions on programmes were answered by the director-general through the minister in the same fashion as had been done in the past by the director of the government department, the NZBS, through previous ministers. Stringer argued the NZBC had no programme independence from that moment.

There is always the question of the extent to which Stringer argued for the NZBC; of the extent to which he argued against issues he thought privately were inevitable. The suspicion is that the man schooled in the public service atmosphere of the NZBS had great difficulty in stepping out of that mould into the assertive independence required from a head of a supposedly independent corporation. This suspicion is added to when one notes that the change from the NZBS to the NZBC did not at all disturb the normal government department continuity of promotion. All the senior NZBC positions went to exNZBS men with the one exception of inaugural news editor and that went to the man from the Department of Tourism and Publicity who had filled the equivalent position for the Government News Service. This continuity of personnel was particularly fateful with regard to the NZBC news service where, for the first years, there was no one at senior level with any training or experience in editorial judgement. But this is just the most severe of many examples of continuity from government department to supposed autonomy. It may be that these men and Stringer in particular, were incapable by background and inclination of winning the good fight for corporation independence. My view is that Hercules himself would have failed to clean the Aegean stables that were the relationship between government and broadcasting in New Zealand. M.H. Holcroft, then editor of the Listener, has observed, 'It is just possible that a strong man could take control and win a true independence, but he would have to be the sort of man I have not seen amongst us in my generation.' The task was beyond Stringer but I do not criticise him for not being the exceptional man of his generation. He did assert independence as best he knew and could, but against insuperable odds.

With financial and programming independence lost before or soon after the NZBC began, the further and continuing struggle concerned the powers of and relationships between the three principals named in the Broad- 


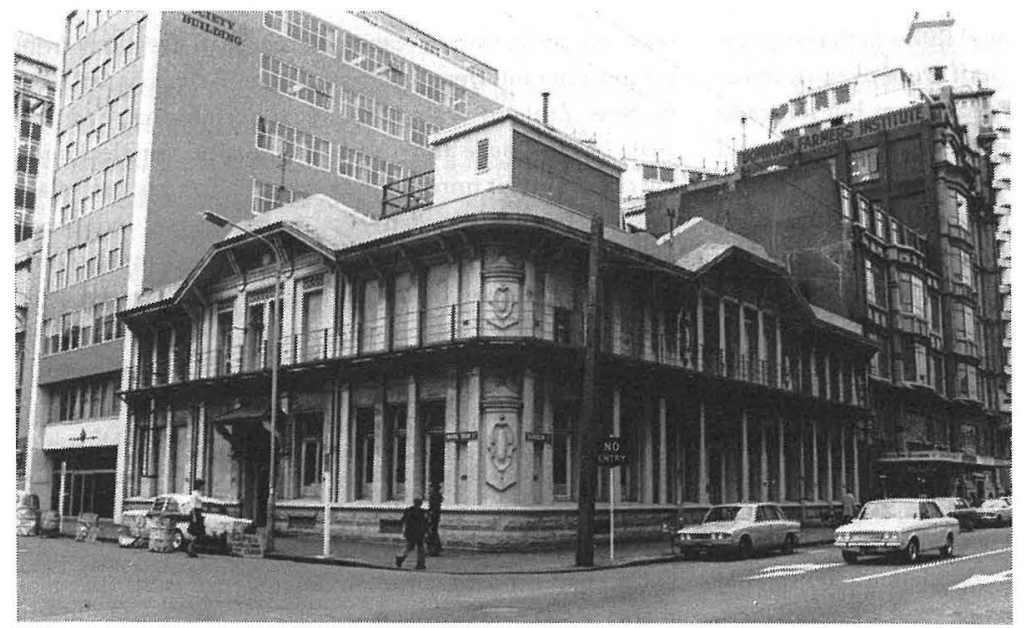

ment department. It is difficult for people to change their attitudes and habits and with a move to a corporation it was desirable to have a change of personnel. However the only new personnel were the board members who, with their delegation of power to Stringer, became less influential. This was exacerbated by Llewellyn's unwavering support of Stringer. The two other board members, James Stenberg and Reeves Harris, told Llewellyn's successor that they went to the monthly

casting Act, the minister, the board, and the directorgeneral. In drafting the legislation Stringer's concern was that none be inordinately stronger than the others. He said: "I drafted the legislation in ' 61 on a theory of checks and balances. I felt that the director-general should be in charge of production ... the chairman and the board should be in charge of policy and the minister was a liaison officer between the board and the government." This very Reithian understanding was originally accepted by the National government with the 1961 cabinet also holding that the board should not be an executive body but be concerned with policy making and regulatory functions only. In the 1961 Broadcasting Act this interpretation was possible and at first was the one followed. However the board was clearly ascendent and could exercise executive power and day to day control if it chose, although this was against the initial understanding and under the first chairman of the board, Frederick Llewellyn, the board was responsible for policy and the director-general exercised day to day executive authority. This practice was aided by Llewellyn's other appointment. He continued as chairman of the University Grants Committee and was very much part-time in the NZBC.

The relationship between the board and the directorgeneral was made explicit at the first board meeting. The Act allowed the board to delegate such of its powers as it saw fit to the director- general and Stringer was given wide-ranging authority. He was authorised to decide the day-to- day activity of the NZBC. Along with authority to enter into contracts, to negotiate for services with other government agencies and to make both policy statements and any other announcements, he was also to 'act within his own discretion on behalf of the corporation in its relations with the government'. While the delegation seemed a full acceptance of the Reithian view in which the director-general and his professional broadcasters were in control, in practice in New Zealand it meant something close to a continuation of the previous govern- board meetings not with the idea of the three board members deciding policy but rather wondering what steps the two of them should take if necessary to counter the director-general's proposals that would be supported, they could be sure, by the chairman. Thus the critical relationship was that between Stringer and the minister, just as it had been in the NZBS.

The weakness of Stringer's understanding of the tripartite division of authority was the role he gave to the minister. Stringer envisaged the minister as a messenger between the corporation and the government. In fact the Minister continued as a dominant authority. Previously the most powerful figure in broadcasting as a government department, Kinsella, the minister over Stringer the director of broadcasting, now continued his earlier relationship with Stringer the director-general of the NZBC. It was unwise to expect that subservient relationship to suddenly become one of assertive independence. Schroder, Stringer's predecessor, and McFarlane, Llewellyn's successor, both regarded the advent of the NZBC as bringing little disturbance to the continuation of NZBS ways of action.

Llewellyn's resigned as chairman in 1965 and was replaced by Charles McFarlane, a former head of the Post and Telegraph Department. With this change Stringer argued that, 'it wasn't long before certain board members were playing around not only with [the director-general's] executive functions but they were impinging on his administrative functions'. Stringer considered board members acted as if they were on the board of a large public company and had no conception that their contribution should be limited to the policy making of the corporation. McFarlane regarded the separation of policy making from

Above: The now demolished building on the corner of Waring Taylor and Featherston streets that was the headquarters of the NZBC's Wellington television station, WNTV1.

Photograph: Evening Post. 
executive functions as untenable and was a more involved chairman. He soon withdrew from Stringer the powers delegated to him by Llewellyn. The change was not merely one of a new attitude by a new chairman. McFarlane's appointment was itself a recognition of a change in the National government's own attitude towards broadcasting. Rather than independence the troublesome corporation required stricter control. This followed from the government's unwillingness either to allow the corporation to determine its own development programme, particularly to bring in a second television channel, or to accept the NZBC's growing assertion of its role as an independent public broadcaster, especially in the area of news and current affairs and most particularly in its reporting and discussion of the then growing war in Vietnam. It was with regard to this topic in particular that the development of one characteristic of public broadcasting, namely an independent journalism section, led to the withdrawal of another characteristic, namely independence from the government. Government attempts to influence the NZBC reporting of that war were met with a gradual assertion of journalistic independence. Stringer's attitude was that if the government cared to declare war it could, as in WWII, immediately appoint a censor and write the news as it saw fit. Until then it had no right to interfere and should be resisted. He also had a realistic understanding that the moment he did censor a piece of news his own journalists would, at their watering hole, inform their counterparts on the Dominion and that he, Stringer, would rapidly lose his credibility and his position.

The mid and late 1960s history of the NZBC includes a gradual cutting away at independence and a re-assertion of external, particularly government, control of broadcasting. McFarlane's appointment was preceded by a change of minister with W J Scott replacing Kinsella. Scott reports Kinsella as 'a bit weak' and his own appointment as being to 'keep a reasonable rein on the NZBC'. But the change of minister indicates a changing government attitude rather than any personal failings of Kinsella. Scott appointed McFarlane and McFarlane's appointment was followed by the enlargement of the board in the 1965 Broadcasting Corporation Amendment Act from three to seven members thus making it capable of more involvement on a day to day basis. The new and subsequent board members appeared to be selected with membership of the National party as a prerequisite, a matter of considerable public discussion during the later public inquiry into the dismissal of Alexander Macleod, editor of the Listener. For Stringer the changes meant a loss of autonomy. He continued to assert the independent authority of the director-general but was now fighting a losing battle. His final defeat came with the 1967 Broadcasting Corporation Amendment Act. By its terms his appointment was changed. No longer was a director-general in office by appointment of the governor-general but on such terms and conditions as the board thought fit. Stringer's original arguable equality with the board was now gone and he was clearly its servant.

In 1960s New Zealand one major characteristic of public broadcasting, namely independence from the government of the day, has a questionable presence. 1960s broadcasting was a formal advance on the previous state broadcasting but in practice resembled those earlier conditions. It had no financial independence from government, and in programming and general administration came under increasing pressure.

\section{STRINGER'S LEGACY}

Ian Cross has spoken of public broadcasting as the battered baby of New Zealand politics. The birth was relatively easy but the early years increasingly difficult. Stringer did not bear special responsibility for that failure to achieve but he did too quickly recognise and accept the inevitability of defeat. The establishment of a news and current affairs section within broadcasting is the major indication of there being public broadcasting in New Zealand but also this establishment is the major reason for the growing government unwillingness to accept independence and for the government's readiness to institute a greater control of broadcasting. In 1985 Stringer reflected, 'I was trying to establish an organisation which contributed to democracy ... It should not be used by one section, one party. It should be used for the benefit of society. And I didn't succeed.' He was over-pessimistic. With its news and current affairs section, the NZBC instituted an increasingly competent journalism which is the major trait distinguishing public from state broadcasting. However the nature of broadcasting control during the 1960s was such that New Zealand broadcasting only partially achieved the status which entitles it to be called public. That status remained contested throughout Stringer's term as director-general. It was a legacy of his contradictions that neither government control nor institutional autonomy was fully asserted.

\section{SOURCES}

Blackburn, Adrian (1974) The Shoestring Pirates, Hodder \& Stoughton. Cross, Ian (1988) The Unlikely Bureaucrat, Allen \& Unwin/Port Nicholson Press.

Day, Patrick (1990) The Making of the New Zealand Press, Victoria University Press.

Day, Patrick (1994) The Radio Years. A History of Broadcasting in New Zealand, Volume One, Auckland University Press.

Holcroft and Schroder interviews, Gregory collection, Dept Public Policy, VUW.

Holcroft, M H (1969) Reluctant Editor, Reed.

Holyoake manuscripts, Alexander Turnbull Library, Wellington.

Minutes of Corporation Meetings, NZBC, National Archives, Wellington.

McFarlane interview, Oral History Archives, National Library, Wellington.

Sound Archives, TX1402, TX1408, TX1444, New Zealand Public Radio, Christchurch. 